\title{
The relationship between body image and social pressure on eating disorders in obese female students
}

\author{
Pahlavie, A.N., Probosari, E., Tsani, A.F.A. and *Dieny, F.F. \\ Department of Nutrition, Faculty of Medicine, Universitas Diponegoro, Indonesia
}

\author{
Article history: \\ Received: 31 January 2020 \\ Received in revised form: 26 \\ March 2020 \\ Accepted: 18 March 2020 \\ Available Online: 30 May \\ 2020
}

Keywords:

Obesity,

Eating disorder,

Body image

DOI:

https://doi.org/10.26656/fr.2017.4(S3).S22

\begin{abstract}
The trend of obesity is increasing among women of childbearing age, especially among female students. In addition to implications on health, obesity also has psychological implications that lead to eating disorders. Several factors that have influenced eating disorders in obese female students include age, body image, obesity level, stress level and social pressure. This study was aimed to analyze the factors that influence eating disorders (obesity level, body image, stress level and social pressure) in obese female students. A cross-sectional study design with ninety obese female students age 19-25 was conducted at Diponegoro University using the simple random sampling technique. Data of eight, height, waist circumference and hip circumference were collected. Eating disorders were measured by Eating Attitude Test-26 (EAT-26) and advanced modification questions adopted from the Eating Disorder Diagnostic Scale (EDDS). Body image was measured by the Body Shape Questionnaire (BSQ). The stress level was obtained by the Perceived Stress Scale (PSS) questionnaire. Social pressure was obtained using the Perceived Sociocultural Pressure Scale (PSPS) questionnaire. This data was analyzed on the Pearson correlation and multiple linear of regression. Significant relationships were observed between age $(p=0.009, r=0.275)$, body image $(p=0.000, r=0.649)$, and social pressure $(\mathrm{p}=0,000, \mathrm{r}=0.461)$ on eating disorder. Otherwise, there was no significant relationship between obesity and stress level with eating disorder $(\mathrm{p}>0.05)$. This study can be concluded that body image and social pressure were the factors that influenced eating disorder in obese female students.
\end{abstract}

\section{Introduction}

Obesity is an excessive accumulation of body fat that leads to various health problems. In 2016, WHO estimated over 1.9 billion adults aged 18 years were overweight and 650 million were obese (World Health Organization, 2018). Based on The Basic Health Research in Indonesia, the proportion of obesity in adults over 18 years increased by 7\% between 2013 and 2018 . In 2013 , the proportion of obesity is about $14.8 \%$ while in 2018 increased to $21.8 \%$ (Badan Penelitian dan Pengembangan Kesehatan, 2018). Based on Semarang's health profile in 2016, the obesity prevalence of population aged $\geq 15$ years in women was higher than men, $11.55 \%$ and $8.32 \%$ respectively (Dinas Kesehatan Semarang, 2016).

The trend of obesity continues to increase among women of childbearing age, including among female students (Poobalan and Aucott, 2016). Obesity has an impact on various health conditions that lead to risk of cardiovascular disease, diabetes, cancer and musculoskeletal disorders. Moreover, obesity has psychological implications triggering the occurrence of eating disorders (Siervo et al., 2013; Lumsden and Hor, 2015). The risk of eating disorders in obese are two to three-fold than non-obese (Musaiger et al., 2013).

Eating disorders defined as a group of mental disorders characterized by abnormal eating behavior and the development of behavior aimed at weight management. There were four types of eating disorders: anorexia nervosa (AN), bulimia nervosa $(\mathrm{BN})$, binge eating disorder (BED), and eating disorder not otherwise specified (EDNOS) (Catalan Agency for Health Technology Assessment and Research, 2009). Types of eating disorders that often occur in obese individuals are BN, BED, and EDNOS (Felipe et al., 2018).

The National Eating Disorders Association (NEDA) estimated about $10 \%$ and $20 \%$ of college students had 
been eating disorder and continued to increase. Data from one tertiary institution during the 13 -year period showed that the number of female students who experienced eating disorders increased from $23 \%$ to $32 \%$ (National Eating Disorders Association, 2013).

The development of eating disorders in obese women of childbearing age especially among female students was influenced by many factors, including obesity levels, body image, stress levels and social pressure. A survey of around 2000 female students at An -Najah National University showed a relatively high prevalence of eating disorders, especially in college students who had a higher body mass index (BMI). The higher of BMI so the higher at risk of eating disorders (Saleh et al., 2018). Research at the University of Ghana on 100 female students showed that there was a significant relationship between body image dissatisfaction with eating disorders (Ntim and Sarfo, 2015). In addition, various studies have shown that high stress levels were associated with increased symptoms of eating disorders (Salafia et al., 2015). Research in Palestine showed that the majority of female students who experience eating disorder have a $\mathrm{BN}$ rather than AN. It caused by families tend to pressure their daughters to eat large amounts, but also hoped that they can maintain the right weight and body size for marriage (Ntim and Sarfo, 2015). Research in Jordan showed a significant correlation between peer influence and the incidence of eating disorders (Al-Sheyab et al., 2018).

Eating disorders first appear in the teenage period, especially in young women. Teenagers have characteristics of body image and often compare their body shapes with their peers and were very easily influenced by the body shapes of the models that they have seen in the media (Sulistyan et al., 2017). A longitudinal study over a 10 years period showed that adolescents became dissatisfied increasingly with their body shape when they got old (Bucchianeri et al., 2013).

The effects of eating disorders in the childbearing period are dehydration, electrolyte and chemical imbalances in the body, decreased heart rate, decreased blood pressure, and increased risk of heart failure and mortality (National Eating Disorders Association, 2012). In addition, women of childbearing age who lose more than normal weight can result in them having poor nutritional status, which can affect the physiological reproductive system (Bayramova, 2017). The effects caused by eating disorders in the period of childbearing age can have an impact on the next period, namely the pregnancy period. Women of childbearing age who have a history of eating disorders are at higher risk of giving birth to babies with low birth weight (LBW), premature babies and caesarean births (Hoffman et al., 2011).

The few studies of eating disorders including obese and non-obese individuals reported minimal differences in psychological functioning on the basis of body mass index (Alberton et al., 2013; Alkazemi et al., 2018). However, both of these studies pooled non-obese and obese participants, so it is not specific to the condition of obesity. It is important to study eating disorders in obese individuals to early detection and determine appropriate interventions for reducing problematic eating patterns. Hence, the current study sought to dig the factors that affected on obese individuals, especially in obese female students.

Unfortunately, research on eating disorder and its factors on obese female student group has not been done much. Therefore, the purpose of this study was to conduct the incidence of disorders and their influencing factors (obesity level, body image, stress level and social pressure) on obese female students.

\section{Materials and methods}

\subsection{Design, location and time}

This research was a cross-sectional study. The study was conducted from June to July 2019 at nine faculties of Universitas Diponegoro, Semarang. The target population in this study was 19-25 years old of obese students in Semarang City, while the outreach population was 19-25 years old of obese students at Diponegoro University. This study was licensed by the Medical Research Ethics Commission of the Faculty of Medicine, Diponegoro University and Kariadi General Hospital Number 282/EC/KEPK/FK UNDIP/VI / 019.

\subsection{Samplings}

Subjects were selected through the anthropometric screening (weight, height, waist circumference, hip circumference) and resulted in 1252 respondents, and those who met the inclusion criteria were 176 respondents. Based on the calculation of the proportion sample size, subjects were obtained by the minimum sample size, 88 subjects. The subjects in this study were 90 subjects selected by simple random sampling technique to avoid dropouts.

\subsection{Data collected}

Height was measured by microtoice with $0.1 \mathrm{~cm}$ accuracy. Bodyweight was measured by digital scales with $0.1 \mathrm{~kg}$ accuracy. Waist and hip circumference measurements used Medline tape with $0.1 \mathrm{~cm}$ accuracy. The inclusion criteria in this study were active college students; $19-25$ years old; have a BMI $>24.9 \mathrm{~kg} / \mathrm{m}^{2}$; willing to be the subject with informed consent; and do 
not have certain diseases that cause extreme reductions in food intake. Those responsible for taking anthropometric data and interviewing the subject are trained personnel.

The independent variables in this study were body image, stress level, social pressure, obesity level, and the dependent variable was eating disorder. Eating disorders were measured using the Eating Attitude Test-26 (EAT26) questionnaire and advanced modification questions adopted from the Eating Disorder Diagnostic Scale (EDDS). The EAT scores were categorized as having the potential to experience eating disorder if the score was $\geq$ 20 and normal if the score $<20$, then the results of the EAT score with the potential to experience eating disorders were assessed using EDDS to determine the type of eating disorder experienced (Garner, Olmsted, Bohr, \& Garfinkel, 1982) (Stice et al., 2000).

Eating disorders were divided into 4 categories: 1) Anorexia nervosa, if it meets the criteria: fear that if you gain weight, feel weight and body shape affect selfevaluation, have not menstruated for the past few months, and BMI $<17.5 \mathrm{~kg} / \mathrm{m}^{2}$; 2) Bulimia nervosa, if it meets the criteria: feeling heavy and body shape affects self-evaluation, repeated binge eating, performing unhealthy compensation behaviors to prevent weight gain at least twice a week for the past 3 months; 3 ) Binge eating disorders, if they meet the criteria: feeling heavy and body shape affects self-evaluation, repeated binge eating, feeling sorry for not being able to control excessive portion of food or gaining weight, experiencing at least 3 of the 5 following characteristics: eating faster than usually; eating until you feel too full; overeating when you don't feel physically hungry; eat alone out of shame with the amount consumed; feeling disgusted or very guilty after the binge eating episode; 4) Eating disorder was not otherwise specified, if it meets the criteria for each category of eating disorder but did not resemble it entirely (Stice et al., 2000).

Obesity was an excessive accumulation of fat in the body that lead to various health problems. The level of obesity in this study was measured on the waist to hip ratio (WHR) using a met-line band with the accuracy of $0.1 \mathrm{~cm}$. WHR was a measurement that reflects the level of obesity and can reflect a person's body shape. Gynoid and android fat distribution types quantified by WHR (Singh, 1994). Obesity level was expressed in $\mathrm{cm}$ and categorized to be high if $>0.8 \mathrm{~cm}$ and low if $<0.8 \mathrm{~cm}$ (Nishida et al., 2011). Body image was a person's perception of the body's appearance, it was obtained by interviews using the Body Shape Questionnaire (BSQ), the BSQ scores were categorized as having a negative body image if the score was $\geq 38$ and a positive body image if the score $<38$ (Evans and Dolan, 1993). Stress is a psychological factor that surrounds many aspects of life and was measured using the Perceived Stress Scale (PSS) questionnaire, PSS scores were categorized as stressed when scores $\geq 16$ and not stressed if scores $<16$ (Cohen et al., 1983). Social pressure consisted of the influence of family, peers and media, it was obtained by interviews using the Perceived Sociocultural Pressure Scale (PSPS) questionnaire, PSPS scores were categorized as getting social pressure if the $\mathrm{T}$ score $\geq 50$ and did not get the social pressure if the $\mathrm{T}$ score $<50$ (Azwar, 2011; Garrusi et al., 2013).

\subsection{Data Analysis}

Univariate analysis was used to describe the characteristics of the subjects by describing each variable including data on age, height, weight, body mass index, waist circumference, hip circumference, WHR, EAT scores, BSQ scores, PSS scores, and PSPS scores. Distribution of data normality using the Kolmogorov Smirnov test. Pearson test correlation was performed to analyze the relationship between the variables of obesity level, body image, stress level and social pressure with eating disorder. Multiple linear regression was performed to determine the most influenced factors on eating disorders. It was performed on body image and social pressure with eating disorder with the enter method.

\section{Results}

The results of screening on 1252 female students age 19-25 at Diponegoro University found that obesity prevalence was $16.1 \%$. After the inclusion and exclusion criteria, the total subjects involved until the end of the study were 90 subjects. The characteristics of the subjects were shown in Table 1.

Table 1 shows that the subjects were age $20.70 \pm 1.22$ years. All subjects classified as obese 1. The mean perception of body image classified into negative body image. The maximum score for eating disorder was 34 , which indicated that there were subjects with eating disorders. The minimum score of stress level was 18.47.

Table 2 shows that $38.9 \%(n=35)$ subjects had the potential to experience eating disorder, and $61.1 \%(\mathrm{n}=$ 55) subjects in the normal category. EDNOS was the greatest frequency of eating disorders, $22.2 \%(n=20)$. The majority of subjects had a negative body image, $90 \%(n=81)$.

Based on Table 3, there was a relationship between body image and social pressure and eating disorder, $p$ $<0.01$. The higher body image score, the greater score of eating disorder. Similarly, the social pressure, the higher 
Table 1. Characteristics of the subjects

\begin{tabular}{lccc}
\hline \multicolumn{1}{c}{ Variables } & Average \pm SD & Minimal & Maximum \\
\hline Age (year) & $20.70 \pm 1.22$ & 19 & 23.5 \\
Height $(\mathrm{cm})$ & $154.38 \pm 5.46$ & 141 & 168.7 \\
Weight $(\mathrm{kg})$ & $68.60 \pm 9.90$ & 53 & 104.1 \\
BMI $\left(\mathrm{kg} / \mathrm{m}^{2}\right)$ & $28.72 \pm 3.42$ & 25 & 42.3 \\
Waist circumference (cm) & $86.84 \pm 8.15$ & 73 & 112.2 \\
Hip circuference (cm) & $104.99 \pm 7.16$ & 90 & 128 \\
WHR (cm) & $0.82 \pm 0.05$ & 0.68 & 0.95 \\
Eating disorder (score) & $16.37 \pm 8.16$ & 3 & 34 \\
Body image (score) & $55.45 \pm 13.81$ & 27 & 88 \\
Stress level (score) & $18.47 \pm 5.36$ & 7 & 36 \\
Social pressure (score) & $23.01 \pm 8.36$ & 10 & 47 \\
\hline
\end{tabular}

Table 2. Frequency distribution of subject characteristics

\begin{tabular}{lcc}
\hline \multicolumn{1}{c}{ Variables } & $\mathrm{n}$ & $\%$ \\
\hline Ages & 52 & 57.8 \\
\hline Late adolescence & 38 & 42.2 \\
Early adult & & \\
\hline Residences & 66 & 73.3 \\
\hline Boarding house & 24 & 26.7 \\
Living with family & & \\
\hline The potential to experience eating disorder & 20 & 22.2 \\
\hline EDNOS & 12 & 13.3 \\
Bulimia nervosa & 3 & 3.3 \\
Binge eating disorder & 55 & 61.1 \\
Normal & & \\
\hline Obesity levels based on WHR & 65 & 72.2 \\
\hline High & 25 & 27.8 \\
\hline Low & & \\
\hline Body image & 81 & 90 \\
\hline Negative body image & 9 & 10 \\
Positive body image & & \\
\hline Stress level & 71 & 78.9 \\
\hline Stress & 19 & 21.1 \\
\hline No stress & 90.3 \\
\hline Gocial pressure & & \\
\hline Not get social pressure & & \\
\hline & & \\
\hline Total & & \\
\hline & & \\
\hline
\end{tabular}

Table 3. Relationship between obesity level, body image, stress level, and social pressure with the occurrence of eating disorders

\begin{tabular}{lcc}
\hline \multirow{2}{*}{\multicolumn{1}{c}{ Variables }} & \multicolumn{2}{c}{ Eating Disorders } \\
\cline { 2 - 3 } & $\mathrm{r}$ & $\mathrm{p}$ \\
\hline Obesity level $(\mathrm{cm})$ & -0.069 & 0.518 \\
Body image (score) & 0.64 & $<0.001$ \\
Stress level (score) & 0.071 & 0.503 \\
Social pressure (score) & 0.461 & $<0.001$ \\
\hline
\end{tabular}

the score social pressure, the greater score of eating disorders.

Body image and social pressure were analyzed in multiple linear regression test, $\mathrm{p}<0.25$. Table 4 shows the factors that mostly influence eating disorders in obese college students was body image. The adjusted $\mathrm{R}^{2}$ value in this study was $0.405=40.5 \%$. This indicated that eating disorder was influenced simultaneously by body image at $40.5 \%$ while the rest was influenced by other confounding variables.

Table 4. The factors that most influenced the occurrence of eating disorder

\begin{tabular}{lccc}
\hline \multirow{1}{*}{ Variables } & \multicolumn{3}{c}{ Eating Disorders } \\
\cline { 2 - 4 } & $\begin{array}{c}\text { Adjusted } \\
\mathrm{R}^{2}\end{array}$ & $\begin{array}{c}\mathrm{B} \\
\text { (Unstandardized } \\
\text { coefficient) }\end{array}$ & $\mathrm{p}$ \\
\hline Body image & & 0.336 & $<0.001$ \\
Social pressure & 0.405 & 0.117 & 0.246 \\
Constanta & & -4.932 & \\
\hline
\end{tabular}

\section{Discussion}

As many as $38.9 \%$ of obese female students at Diponegoro University has the potential to experience eating disorder. The prevalence of eating disorders was higher than the prevalence in South Australia in the obesity group by $5.8 \%$ (Da Luz et al., 2017). However, it was lower when compared to the prevalence of eating disorders at Kuwait University in all groups of nutritional status that were equal to $46.4 \%$. This was caused by errors in perceiving body weight, regardless of their actual BMI (Alkazemi et al., 2018). Eating disorders were defined as a group of mental disorders characterized by abnormal eating behavior and behavioral development aimed at managing weight. There were 4 types of eating disorders: anorexia nervosa (AN), bulimia nervosa (BN), binge eating disorder (BED), and eating disorder not otherwise specified (EDNOS) (Catalan Agency for Health Technology 
Assessment and Research, 2009) Types of eating disorders that often occur in obese individuals are $\mathrm{BN}$, BED, and EDNOS. (Felipe et al., 2018)

Based on the results of the study showed subjects who experienced a BED at $3.3 \%, 13.3 \%$ of $\mathrm{BN}$, and $22.2 \%$ of EDNOS. Most subjects were classified as EDNOS. Someone who experiences this type of eating disorder have symptoms that were almost the same as sufferers of $\mathrm{AN}, \mathrm{BN}$, and BED but did not entirely similar, meaning they had more than one symptom of eating disorder, for example, they have symptoms of BN but also have symptoms of BED. Factors that influence the occurrence of eating disorders included body image, obesity level, stress level, and social pressure. This study found a significant relationship between body image and social pressure with eating disorders.

This study also found that the majority of subjects (90\%) had a negative body image. This was consistent with a previous study in Yogyakarta where all subjects in the obese female student group had a negative body image. The high number of subjects who have negative body image was influenced by the peak of attention on the appearance that occurs in adolescence and age 20 years (Ayu et al., 2015).

There were significant positive relationships between body image and eating disorders among obese female students. This finding was in line with a previous study at the University of Ghana that negative feelings about body image have a strong relationship with eating disorders. Someone with a distorted body image considers their body ugly or even terrible for others. This negative body image makes a person enter into various habits that affect eating and daily activities (Ntim and Sarfo, 2015). Beauty and attraction are things that make a woman able to attract the attention of the opposite sex and her environment. Every woman, of course, wants to display an attractive physical appearance, in order to attract the attention of the opposite sex. Obese individuals often reject the state of their physical condition so that they appear to be isolated because they feel inferior (Fernando, 2019).

Psychologically, a person with a negative body image does not have good self-confidence, so his thinking patterns will lead her to adopt inappropriate eating behaviours in order to realize the desire to obtain an ideal body shape without regard to her body's nutritional needs (Rahayu and Dieny, 2012).

Media propaganda significantly increased negative body image in women. The assumption that media exposure that portrays a thin body was ideal relates to a body image for women (Chairani, 2018). This causes one to think that the ideal body was a thin body so as to make them try to lose weight. In addition, body image was also influenced by family and peers. Comments made by parents and family members have a big influence on the child's body image. Families often instruct to go on a diet, give slimming drugs, and give a lot of comments on body shape as compared to other family members who are not obese. Obese individuals also often compare themselves with their friends, giving rise to the desire to have a thin and ideal body like their peers, this can cause feelings of inferiority and shame. Interpersonal relationships make a person tend to compare themselves with others and the feedback received affects selfconcepts including feelings towards physical appearance (Fernando, 2019).

About $43.3 \%$ of the subjects in this study get social pressure. The data showed that there was a significant positive correlation between social pressure and eating disorders among obese female students. Most of the social pressure experienced by the subject was due to the influence of family and peers, ranging from ridicule to the drive to become thinner and the influence of the media. Previous research from An-Najah National University explained that families tend to pressure their daughters to eat in large quantities, but also hope that they maintain the right weight and body size for marriage later (Saleh et al., 2018).

On the other hand, peers influence the development of eating disorders through modeling, discussion of diet and weight loss, teasing, and the extent to which they become thin will increase the liking between friends. Teasing is defined as another way of influencing eating because it affects the level of emotional disturbances (Gast and Meyer, 2008). A previous study in Jordan explained that individuals involved in body comparisons and conversations about appearance and weight with peers and ideas and thoughts embedded in the mind that they will be more accepted and popular if they have a thinner body (Al-sheyab et al., 2018).

In addition, the media also played a role in the occurrence of eating disorder disorders (Ul-abideen et al., 2011). The role of the media as supporting the ideal thin body shape has instilled ideal body standards that were unhealthy and unrealistic, especially among young women (Siervo et al., 2013). Messages through social media, television, internet, magazines and newspapers bombard women with advice on how to lose weight faster, exercise more, and eat less to be thinner. These messages openly state that being thin will make a woman look more attractive, increase her popularity, lead to job success and get an ideal partner (Cassel and Gleaves, 2013). 
The prevalence of stressed female students in this study was quite high at $71.9 \%$. The high number of subjects experiencing stress can be influenced by multidimensional factors (biological, economic, social, and cultural). In this study, stress levels were not related to eating disorder. This finding was different from the results of research conducted in the United States which explained that stress was associated with the occurrence of eating disorders (Shelton and Valkyrie, 2010). There may be other factors that influence feelings of stress in individuals, one of the most powerful factors in influencing a person's stress level was social support. Social support is one of the factors that influence how to manage stress or coping mechanism. Social support is the availability of people who can be trusted and can make individuals feel cared for and valued as humans. Social support can be a mediator between stress and selfadjustment and can withstand the effects caused by feelings of stress. Sources of social support among students mostly came from peer groups (Fitriani, 2011).

When at stress level, the body releases the hormone cortisol into the bloodstream. Possibly with social support, there is a role for anti-stress hormones, such as the hormone oxytocin. The hormone oxytocin can provide anti-stress effects, one of which by lowering cortisol levels in the body. Positive interactions involving touch and psychological support in a person can trigger the release of the hormone oxytocin in the body. Stress among students is common, related to lecture problems, personal problems with family, and people around (Noe et al., 2019). So it can be assumed that feelings of stress caused can still be adapted by those concerned.

The mean WHR subject in this study was $0.82 \mathrm{~cm}$, this indicated a high level of obesity among female college students because it has an average WHR higher than the cut-off value for South Asian women which is $\geq$ $0.8 \mathrm{~cm}$ (Nishida et al., 2011). But the results of this study showed no significant relationship between the level of obesity with eating disorder. This finding was not in line with the previous study in India which stated that WHR was associated with eating disorders (Chahar, 2015). Obesity was a popular risk factor in developing the potential for eating disorders. However, eating disorders can be experienced by groups of adolescents or early adults who are not obese (Alberton et al., 2013; Alkazemi et al., 2018). This study showed that people with obesity levels based on WHR in all conditions both high and low may be able to influence the occurrence of eating disorders or vice versa. The level of obesity was not the only factor that triggered a person experiencing an eating disorder. There were other driving factors that were proven in this study: body image and social pressure. Eating disorder is not only caused by body shape, but also due to the environment that is not supportive such as ridicule of fat body shape, the demands of ideal body shapes when married, and the media which describes that thin is the ideal body shape.

Obese individuals must have a positive body image, not blame their body shape or prolonged sadness so as not to decide to make weight loss in ways that are not healthy so that the potential to experience eating disorders. A person who was obese with eating disorder had a high risk of several medical and psychosocial complications. Individuals with obesity and eating disorder were closely related to episodes of binge eating. Binge eating in obese individuals was related to mental health and poor quality of life, besides binge eating can also reduce work productivity and inhibit weight loss in obese individuals (Felipe et al., 2018).

The childbearing period is an important phase in preparation for becoming a prospective mother so that it is demanded to fulfill nutritional needs (Rahayu and Dieny, 2012). Obese individuals who have the potential to experience eating disorder can experience a lack of intake of nutrients that are needed in the childbearing period. Obesity in women childbearing age must be corrected, but not in unhealthy ways that can lead it to implement inappropriate eating behaviours that have the potential to experience eating disorders.

\section{Conclusion}

As many as $38.9 \%$ of obese female students at Diponegoro University have the potential to experience eating disorder. Subjects who experienced BED were $3.3 \%$, subjects BN were $13.3 \%$, and EDNOS was $22.2 \%$. There were relationships between body image and social pressure on the incidence of eating disorders in obese college students. The factor that most influences eating disorder in obese college students was body image. Obese students who have the potential to experience eating disorders need to be equipped with knowledge about nutrition through nutrition education and counseling. Because fighting obesity is not just eating less and exercising more, so changes in body perception and eating are needed to lose weight in obese individuals who have the potential to experience eating disorder.

\section{Conflict of interest}

Authors declare no conflict of interest.

\section{Acknowledgments}

We would like to thank the subjects of the study and Universitas Diponegoro for their willingness to help 
smooth the implementation of this study. This research was funded by the 2019 Universitas Diponegoro Faculty of Medicine Research and Implementation Research grant.

\section{References}

Al-sheyab, N.A., Gharaibeh, T. and Kheirallah, K. (2018). Relationship between peer pressure and risk of eating disorders among adolescents in Jordan. Journal of Obesity, 2018, 7309878. https:// doi.org/10.1155/2018/7309878

Alberton, V.C., Dal-Bo, M.J., Piovezan, A.P. and Silva, R.M.D. (2013). Abnormal eating behaviors among medical students at a university in Southern Santa Catarina, Brazil. Revista Brasileira de Educacao Medica, 37(1), 15-20. https://doi.org/10.1590/S0100 $-55022013000100003$

Alkazemi, D., Zafar, T., Ebrahim, M. and Kubow, S. (2018). Distorted Weight Perception Correlates with Disordered Eating Attitudes in Kuwait College Women. International Journal of Eating Disorder, 51(5), 449-458. https://doi.org/10.1002/eat.22852

Ayu, D., Wardani, K., Huriyati, E. and Hastuti, J. (2015). Obesitas, body image, dan perasaan stres pada mahasiswa di daerah Istimewa Yogyakarta. Jurnal Gizi Klinik Indonesia, 11(4), 161-169. https:// doi.org/10.22146/ijen.22649

Azwar, S. (2011). Sikap Manusia Teori dan Pengukurannya. 2nd ed. Yogyakarta, Indonesia: Pustaka Pelajar. [In Bahasa Indonesia].

Badan Penelitian dan Pengembangan Kesehatan. (2018). Hasil Utama Riset Kesehatan Dasar 2018. RISKESDAS. Jakarta: Kementerian Kesehatan Republik Indonesia. [In Bahasa Indonesia].

Bayramova, A. (2017). Eating disorders and reproduction in women. Journal of Gynecology and Women's Health, 5(3), 1-7. https://doi.org/10.19080/ JGWH.2017.04.555663

Bucchianeri, M.M., Arikian, A.J., Hannan, P.J., Eisenberg, M.E. and Neumark-Sztainer, D. (2013). Body dissatisfaction from adolescence to young adulthood: Findings from a 10-year longitudinal study. Body Image, 10(1), 1-7. https:// doi.org/10.1016/j.bodyim.2012.09.001

Cassel, D.K. and Gleaves, D.H. (2013). The Encyclopedia of Obesity and Eating Disorders. Choice Reviews Online. Vol.32, $3^{\text {rd }}$ ed. New York: Facts On File Library of Health and Living.

Catalan Agency for Health Technology Assessment and Research (Ed.). (2009). Clinical Practice Guideline for Eating Disorders. 1st ed. Spain, Barcelona: Catalan Argency for Health Technology Assessment and Research (AATRM).

Chahar, P.S. (2015). Survey of eating disorder in relation to waist-to- hip ratio and waist-to-height ratio among school going children. International Journal of Sport and Research, 4(6), 2095-2098.

Chairani, L. (2018). Body shame dan gangguan makan. Buletin Psikologi, 26(1), 12-27. https:// doi.org/10.22146/buletinpsikologi.27084

Cohen, S., Kamarck, T. and Mermelstein, R. (1983). A global measure of perceived stress. Journal of Health and Social Behavior, 24(4), 385-396. https:// doi.org/10.2307/2136404

Da Luz, F.Q., Sainsbury, A., Mannan, H., Touyz, S., Mitchison, D. and Hay, P. (2017). Prevalence of obesity and comorbid eating disorder behaviors in South Australia from 1995 to 2015. International Journal of Obesity, 41(7), 1148-1153. https:// doi.org/10.1038/ijo.2017.79

Dinas Kesehatan Kabupaten Semarang. (2016). Profil Kesehatan Kabupaten Semarang. Semarang, Indonesia: Dinas Kesehatan Kabupaten Semarang. [In Bahasa Indonesia].

Evans, C. and Dolan, B. (1993). Body shape questionnaire: derivation of shortened "alternate forms." International Journal of Eating Disorder, 13 (3), 315-321. https://doi.org/10.1002/1098-108X (199304)13:3<315::AID-EAT2260130310>3.0.CO;2 $-3$

Fernando, M.L. (2019). Gambaran citra tubuh pada wanita dewasa awal yang mengalami obesitas. Jurnal Ilmu Psikologi Terapan, 7(1), 101-118. [In Bahasa Indonesia]. https://doi.org/10.22219/ jipt.v7i1.6369

Fitriani, A.R. (2011). Perbedaan Tingkat Psychological Distress pada Mahasiswa Universitas Indonesia Berdasarkan Kepemilikan Teman (Received Peer Social Support) pada Tahun 2010 dan 2011. Jakarta: Universitas Indonesia. [In Bahasa Indonesia].

Garner, D.M., Olmsted, M.P., Bohr, Y. and Garfinkel, P.E. (1982). The Eating Attitudes Test: psychometric features and clinical correlates. Psychological Medicine, 12(4), 871-878. https://doi.org/10.1017/ S0033291700049163

Garrusi, B., Garrusi, S. and Baneshi, M.R. (2013). Assessment of psychometric properties of Persian version of Perceived Socio-cultural Pressure Scale (PSPS). Journal of Pakistan Medical Association, 63 (4), 468-471.

Gast, J. and Meyer, T.A. (2008). The effects of peer influence on disordered eating behaviour. Journal of School Nursing, 24(1), 36-42. https:// doi.org/10.1177/10598405080240010601 
Hoffman, E.R., Zerwas, S.C. and Bulik, C.M. (2011). Reproductive issues in anorexia nervosa. Expert Review of Obstetrics and Gynecology, 6(4), 403-414. https://doi.org/10.1586/eog.11.31

Lumsden, M.A. and Hor, K. (2015). Impact of obesity on the health of women in midlife. The Obstetrician and Gynaecologist, 17(3), 201-208. https:// doi.org/10.1111/tog.12199

Musaiger, A.O., Al-Mannai, M., Tayyem, R., Al-Lalla, O., Ali, E.Y.A., Kalam, F., Benhamed, M.M., Saghir, S., Halahleh, I., Djoudi, Z. and Chriane, M. (2013). Risk of disordered eating attitudes among adolescents in seven Arab countries by gender and obesity: A cross-cultural study. Appetite, 60, 162167. https://doi.org/10.1016/j.appet.2012.10.012

National Eating Disorders Association. (2012). Health Consequences. Retreived from National Eating Disorders Association website: https:// www.nationaleatingdisorders.org/healthconsequences

National Eating Disorders Association. (2013). Eating disorder on the college campus : A national survey of programs and resources. Retreived from National Eating Disorders Association website: https:// www.nationaleatingdisorders.org/sites/default/files/ CollegeSurvey/CollegiateSurveyProject.pdf

Noe, F., Kusuma, F.H.D. and Rahayu H., W. (2019). Hubungan Tingkat Stres dengan Eating Disorder pada Mahasiswi yang Tinggal di Asrama Putri Universitas Tribhuwana Tunggadewi. Nursing News, 4(1), 159-168. [In Bahasa Indonesia].

Ntim, C.N. and Sarfo, J.O. (2015). Body image and eating disorders among female students: a pilot nutritional psychology study in Ghana. Journal of Advocacy, Research and Education, 2(1), 54-57.

Poobalan, A. and Aucott, L. (2016). Obesity Among Young Adults in Developing Countries: A Systematic Overview. Current Obesity Report, 5, $2-$ 13. https://doi.org/10.1007/s13679-016-0187-x

Rahayu, S.D. and Dieny, F.F. (2012). Citra tubuh, pendidikan ibu, pendapatan keluarga, pengetahuan gizi, perilaku makan dan asupan zat besi pada siswi SMA. Media Medika Indonesiana, 46(3), 184-194. [In Bahasa Indonesia].

Salafia, E.H.B., Jones, M.E., Haugen, E.C. and Schaefer, M.K. (2015). Perceptions of the causes of eating disorders: A comparison of individuals with and without eating disorders. Journal of Eating Disorders, 3, 32. https://doi.org/10.1186/s40337-015 $-0069-8$

Saleh, R.N., Salameh, R.A., Yhya, H.H. and Sweileh, W.M. (2018). Disordered eating attitudes in female students of An-Najah National University: a crosssectional study. Journal of Eating Disorders, 6(1), 16. https://doi.org/10.1186/s40337-018-0204-4

Shelton, V.L. and Valkyrie, K.T. (2010). College student stress: A predictor of eating disorder precursor behaviors. The Alabama Counseling Association Journal, 35(2), 14-27.

Siervo, M., Montagnese, C., Muscariello, E., Evans, E., Stephan, B.C.M., Nasti, G., Papa, A., Ianneti, E. and Colantuoni, A. (2013). Weight loss expectations and body dissatisfaction in young women attempting to lose weight. Journal of Human Nutrition and Dietetics, 27(S2), 84-89. https://doi.org/10.1111/ jhn. 12078

Singh, D. (1994). Ideal female body shape : Role of body weight and waist-to-hip ratio. International Journal of Eating Disorders, 16(3), 283-288. https:// doi.org/10.1002/1098-108X(199411)16:3<283::AID -EAT2260160309>3.0.CO;2-Q

Stice, E., Telch, C.F. and Rizvi, S.L. (2000). Development and validation of the eating disorder diagnostic scale: A brief self-report measure of anorexia, bulimia, and binge-eating disorder. Psychological Assessment, 12(2), 123-131. https:// doi.org/10.1037/1040-3590.12.2.123

Sulistyan, A., Huriyati, E. and Hastuti, J. (2016). Distorsi citra tubuh, perilaku makan, dan fad diets pada remaja putri di Yogyakarta. Jurnal Gizi Klinik Indonesia, 12(3), 99-107. [In Bahasa Indonesia]. https://doi.org/10.22146/ijen.22644

Ul-abideen, Z., Latif, A., Khan, S. and Farooq, W. (2011). Impact of Media on Development of Eating Disorders in Young Females of Pakistan. International Journal of Psychological Studies, 3(1), 122-147. https://doi.org/10.5539/ijps.v3n1p122

Nishida, C., Ko, G.T. and Kumanyika, S. (2011). Body fat distribution and noncommunciable disease in populations: overview of the 2008 WHO Expert Consultation on Waist Circumference and Waist-Hip Ratio. European Journal of Clinical Nutrition, 64, 25. https://doi.org/10.1038/ejen.2009.139

World Health Organization. (2018). Obesity and overweight. Retrieved January 24, 2019, from WHO website: https://www.who.int/news-room/factsheets/detail/obesity-and-overweight 